UDC 338.43

JEL Classification: Q13; Q16

DOI: https://doi.org/10.32317/2221-1055.202008052

R. M. BEZUS, doctor of economic sciences, professor

M. O. DUBCHAK

\title{
Genesis and development of agricultural advisory services in Ukraine
}

The purpose of the article is to investigate the initiation, current issues, and further development of agricultural advisory services in Ukraine.

Research methods. The research uses dialectical methods of cognition and monographic method (for the analysis of legislation, works of Ukrainian and foreign scientists on the problem of advisory services in agriculture), empirical and graphical methods (to assess and demonstrate the structure of organizational forms and marketing methods of advisory services), abstract logical methods (for theoretical generalizations and formulation of conclusions).

Research results. The study has highlighted that agricultural advisory services institution is a powerful tool to help smallholders in Ukraine break the cycle of low productivity, vulnerability, and poverty. By providing farmers with knowledge and tools about modern agricultural practices, agricultural advisory services can be a critical force for change. However, the development of these organizations in Ukraine now meets such challenges as low level of governmental support for agriculture advisory activities, understaffing of agricultural advisory services, and confusing mechanisms of cooperation with formal institutions for agricultural advisory services organizations in Ukraine etc.

Scientific novelty. This study has investigated the current perspectives and challenges of agricultural advisory services in Ukraine. It has highlighted perspective points of development and improvement for such organizations to support further rural development in Ukraine. In particular, governmental development programs to promote the agricultural advisory activities for both rural smallholder farmers and local authorities, creating the mechanisms of cooperation between agricultural advisory service organizations and formal institutions in Ukraine, support of professional development for advisors and experts, etc.

Practical significance. Summarising the achieved and analysed data, scientists and policymakers to develop the support programs for agricultural advisory service organizations to support rural smallholder businesses and to improve the living standards of rural communities may use the results of the study. Tabl.: 2. Figs.: 3. Refs.: 14.

Keywords: agricultural advisory services; farming cooperatives; rural development; advisors; expert advisors; smallholder business.

Bezus Roman Mykolaiovych - doctor of economic sciences, professor, professor of the department of marketing, Dnipro State Economic and Agrarian University (25, S. Efremova St., Dnipro, 49600)

E-mail: bezusrm@gmail.com

ORCID iD https://orcid.org/0000-0001-5284-9178

Dubchak Maryna Olehivna - 2nd year master's student of the faculty of management and marketing, Dnipro State Economic and Agrarian University (25, S. Efremova St., Dnipro, 49600)

E-mail: marina.dubchak.daas@gmail.com

Scientific problem. The agricultural advisory services (AAS) in Ukraine are a significant element of the subsequent development of the agricultural sector of its economy. The knowledge dissemination among the agricultural producers, their support with pieces of training and information is essential in the vast majority of developed countries. The success of the agricultural sector largely depends on new technologies, market conditions, and organizational changes to develop progressively. Ukrainian advisory services must become an important element of internal agricultural policy to disseminate the knowledge effectively. Therefore, it is

(c) R. M. Bezus, M. O. Dubchak, 2020 important to substantiate the theoretical and methodological foundations of the organization and development of the AAS, to analyze the current state of the AAS institution in Ukrainian, and to identify the problems and prospects for its development. All above determine the article's relevance.

Analysis of recent research and publications. In recent years, studies on advisory services issues have become more recent than in the previous decade. The scientific works of such Ukrainian researches as 0 . Halych, O. Sosnovs'ka [3], M. Kropyvko [6], M. Bezkrovnyy [1, 7] are devoted to problems of the formation and development of advisory services in Ukraine. In the works written by 
such international scientists as Anne W. Van den Ban [11], Naswem A., Daudu S. [13], authors emphasize that the success of the agricultural sector of any country largely depends on the development of new technologies, market conditions, and organizational changes needed for further development.

The purpose of the article is to investigate the initiation, current issues, and further development of agricultural advisory services in Ukraine.

Research results. The history of the AAS in Ukraine has begun with the reform of the agricultural sector when public authorities began to rethink their functions. It started with new private farms understand they prefer a piece of advice rather than strict instructions on technologies, plant varieties and effective pesticides, loans quality equipment, etc. Eventually, the advisers have realized that all of this is from their area of responsibility. Such a process began in 1995 when the Center for Privatization and Agrarian Reform appealed to the European Commission for assistance in establishing an advisory services organization in the L'viv region. As a result, it was established in 2000. Over time, advisory services appeared in almost every region of Ukraine. The establishing of the AAS institution arise several questions concerning the coordination of advisors' activities, the exchange of experience, and the dissemination of information, that is, the legalization of consultations in the legal framework of Ukraine [10].

In 2003, the AAS organizations in 17 regions initiated the NGO "National Association of Agricultural Advisory Services of Ukraine" (NAAASU). Its main purpose was to promote the improvement of welfare in rural communities and rural development by spreading the knowledge and skills among such communities, and agricultural producers and by protecting the social, economic, professional, and other common interests of its members. In Ukraine, the Verkhovna Rada legally determined the agricultural consulting by the Law of Ukraine "On Agricultural Advisory Services" adopted in 2004. According to this Law, up to $5 \%$ of the budget for the agricultural producers' support programs is for the certification of advisors, advisory services, and for the financing of advisory services [9].

Nowadays, it is generally agreed that the creation of the AAS institution in Ukraine is based on both domestic and international experience. Assisted by the Commission on Agrarian Policy under the President of Ukraine and the Ministry of Agrarian Policy of Ukraine, international support for advisory activities has become systemic (Table 1 ).

Table 1. International donor organizations supporting AAS organizations in recipients regions of Ukraine

\begin{tabular}{|c|c|c|c|c|c|c|c|c|c|c|c|c|c|c|c|c|c|}
\hline \multirow[b]{2}{*}{ Donor organizations } & \multicolumn{17}{|c|}{ Regions of Ukraine } \\
\hline & $\stackrel{\vec{\lambda}}{\vec{x}}$ & $\begin{array}{l}\frac{x}{u n} \\
\frac{n}{5} \\
\frac{0}{J} \\
J\end{array}$ & 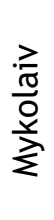 & 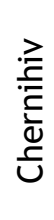 & $\begin{array}{l}\frac{x}{u} \\
\tilde{y} \\
\stackrel{0}{0} \\
0\end{array}$ & $\frac{\tilde{n}}{\tilde{d}}$ & 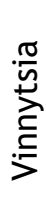 & 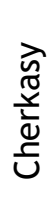 & 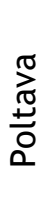 & 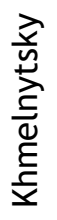 & $\sum_{\overline{0}}^{\circ}$ & $\frac{\circ}{\frac{0}{a}}$ & $\stackrel{\geq}{\geq}$ & 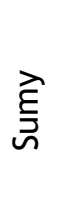 & 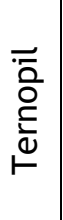 & 产 & $\begin{array}{l}\frac{c}{0} \\
\frac{n}{4} \\
\frac{c}{x}\end{array}$ \\
\hline European Commission & & + & + & + & & & & & & & & & & & & & \\
\hline $\begin{array}{l}\text { The Government of } \\
\text { Great Britain }\end{array}$ & + & & & & + & + & & & & & & & & & & & \\
\hline $\begin{array}{l}\text { The Government of the } \\
\text { Federal Republic of } \\
\text { Germany }\end{array}$ & + & & & & & & + & + & + & & & & & & & & \\
\hline $\begin{array}{l}\text { The Government of the } \\
\text { USA }\end{array}$ & & & & & & & + & + & & + & & & & & & & \\
\hline $\begin{array}{l}\text { The Government of } \\
\text { Canada }\end{array}$ & & & & & & & & & & & + & + & + & + & & & \\
\hline $\begin{array}{l}\text { The Government of } \\
\text { Denmark }\end{array}$ & & & & & & & & & & & & & & & + & & \\
\hline $\begin{array}{l}\text { The Government of the } \\
\text { Netherlands }\end{array}$ & & & & & & & & & & & & & & & & + & \\
\hline $\begin{array}{l}\text { International Finance } \\
\text { Corporation with the } \\
\text { governments of Swe- } \\
\text { den and Canada }\end{array}$ & & & & & & & & & & & & & & & & & + \\
\hline
\end{tabular}

Source: Compiled by authors. 
The projects of international technical assistance have also contributed to the development of advisory services in the regions of Ukraine. Initially, such assistance programs plan that eventually all of AAS organizations would gather into a single system, following the world experience. However, this process has not been finished yet [8].

As of 15.05.2020, the Register of agricultural advisory services ratified by the Ministry of development of economy, trade, and agri- culture of Ukraine contains 21 organizations. However, according to the NGO "NAAASU" and Google search, there are 80 organizations that provide consulting services in Ukraine. The productive functioning of these AAS mostly depends on the necessary funds. In Ukraine, there is a critical problem of choosing an ownership form for the most effective advisory activities with minimal costs. The organizational and legal structure of the AAS is in Figure 1.

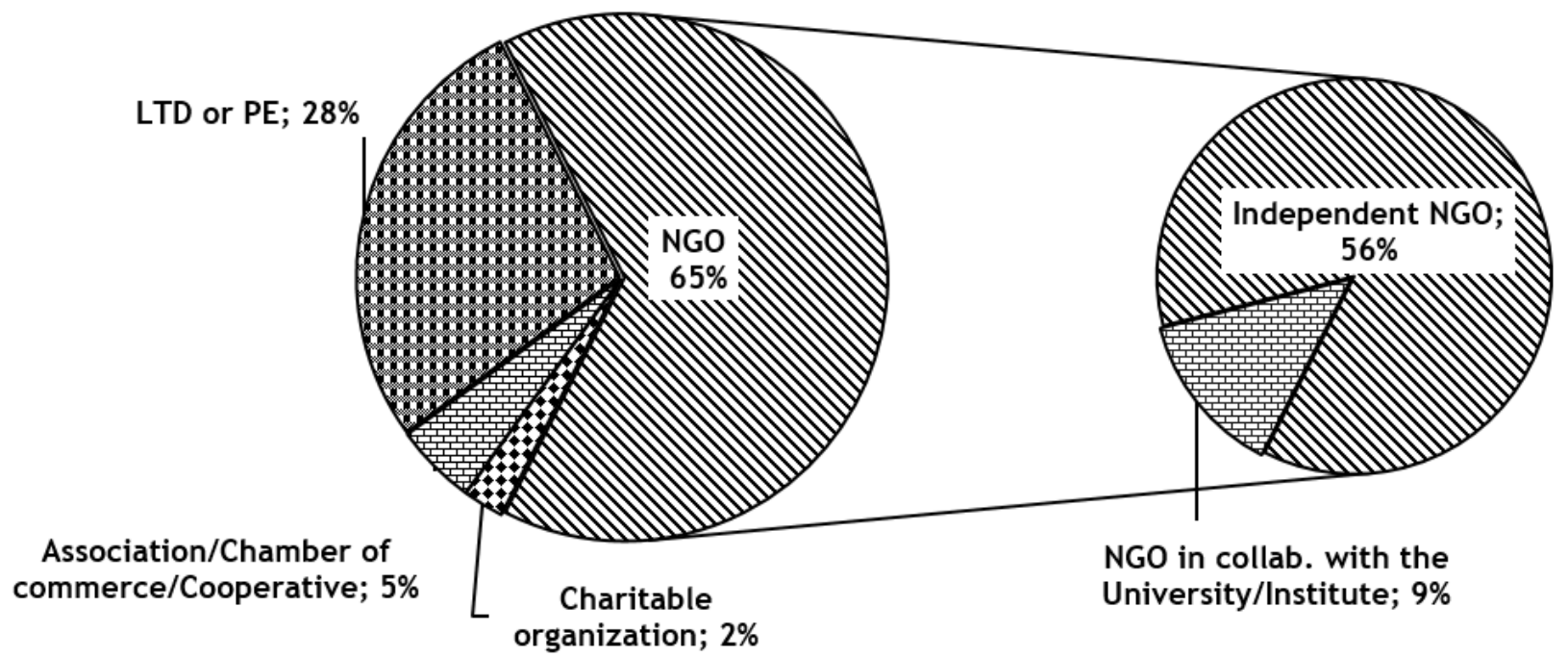

Figure 1. The organizational and legal structure of the AAS

Source: Created by authors.

Figure 1 shows that $66 \%$ of all advisory service organizations have a non-governmental status, $28 \%$ of those are Limited (LTD) or Private entrepreneur $(\mathrm{PE})$. The legal form of NGO has some limitations for AAS in case of providing services for commercial clients (other than project recipients). To avoid the limitations Ukrainian NGOs have to find LTD or PE that operates freely with such clients. Technically, the personnel of AAS works in two organizations at the same time. According to the Classifier of Economic Activities (CEA), most of NGOs operate within 94.99 CEA (activities of other civil organizations, not involved in other groups). 35\% of LTD operate based on
70.22 CEA implying "Advice on business and management".

Different factors are influencing the financing of an advisory organization. The mechanisms of its financing can affect the decisions made by the advisory organization relating to goals, target groups, advisory methods used, internal organization, and cooperation with other organizations promoting agricultural development. Decisions made regarding these issues carry several implications for the ways of AAS supports farmers. Table 2 shows the Sources of financing of the AAS depending on its legal structure [11, $1 \mathrm{p}]$.

Table 2. Sources of financing of the AAS

\begin{tabular}{|c|c|c|c|}
\hline Legal structure Financing & Grants & Business & Government \\
\hline LTD & $+/-$ & + & + \\
\hline NGO & + & - & - \\
\hline Charitable organization & + & + & - \\
\hline
\end{tabular}

Source: Compiled by authors.

Nowadays, the government should pay more attention to the agricultural services institution development as eventually it will get more public benefits than direct participants in terms of amount of tax payments from register and successfully operating rural farmers and 
connected businesses. Big businesses will invest in advisory services only if they sure that such services promote sales. The grants allow AAS to participate in international technical assistance projects; furthermore, some NGOs were initiated by international projects. Due to the lack of information about such projects, it is impossible to make a complete portrait of their activities. Not all of the organizations consider it necessary to promote themselves on the Internet. Figure 2 shows the structure of promotion channels used by the AAS.

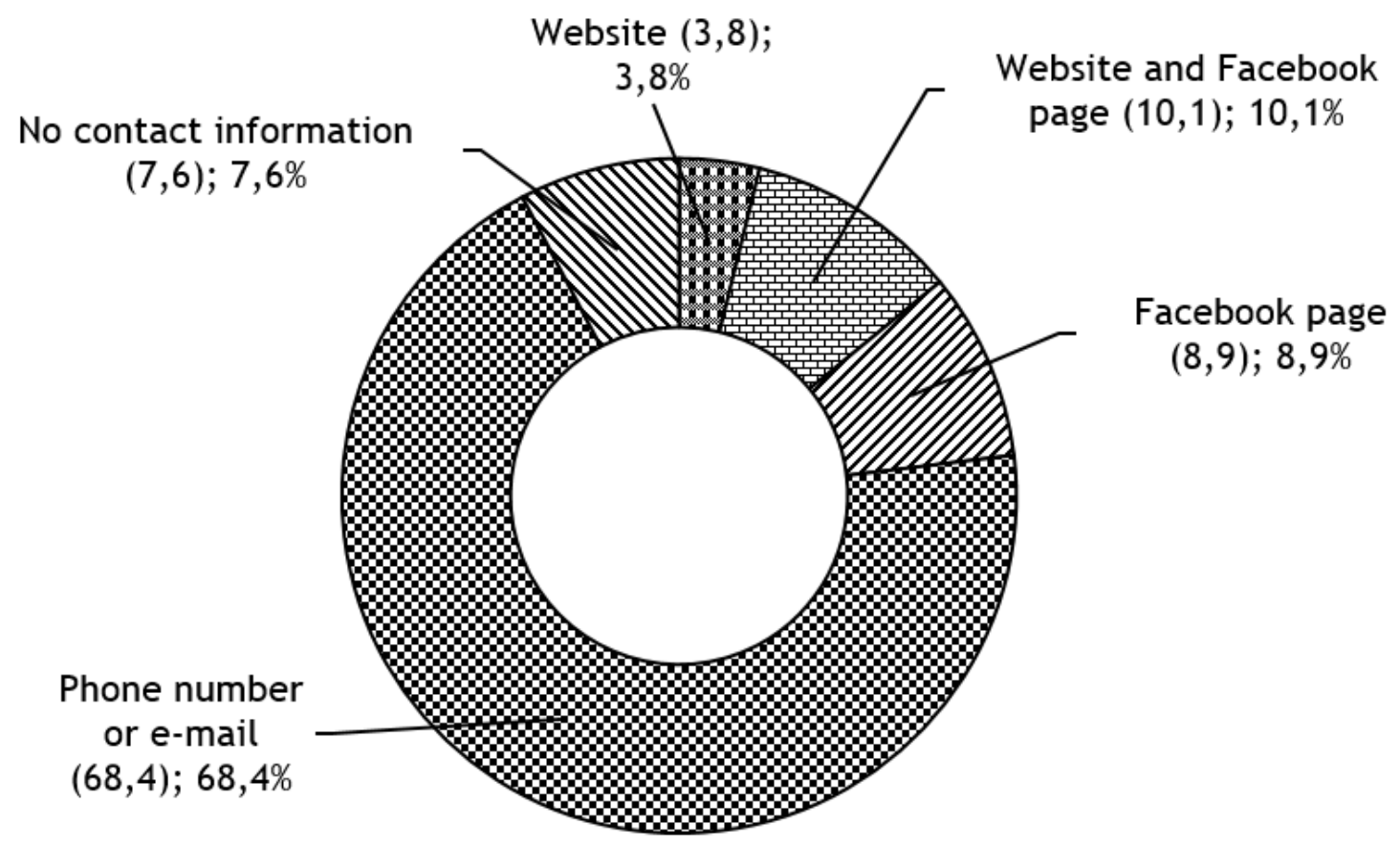

Figure 2. The structure of promotion channels

Source: Created by the authors.

Only about $14 \%$ of AAS organizations have their website or page on social media. The lack of information negatively affects the promotion of their advisory services and Facebook groups have a very little number of active participants. Therefore, social media marketing aimed at increasing user participation must include fast replies to queries posted, commenting on posts made by others, engaging in discussions, mentioning clients in posts and comments, etc. Communication is the crux of social media marketing and it should be the main instrument of any AAS in social media [13, 4 p].

In Ukraine, the average number of AAS per one oblast is 3, and 7 AAS are in Kyiv. The most of AAS organizations is in the Chernihiv oblast, specifically 10, Donetsk oblast has 7 AAS (as of 2014), Vinnytska and Chernivetska oblasts have 5 AAS each. The information on numbers in other oblasts of Ukraine is in Figure 3.

According to the Register of AAS, the average number of advisers in the advisory services organization is 4 persons. The total number of employees of AAS in the Register of AAS is 85 persons, 14 of them have a science degree.

As of March of 2020, the Register of agricultural advisers and experts-advisers has
531 persons, among them 284 advisers and 247 expert-advisers. It is important to note the difference between these two professional roles. An agricultural advisor is a registered specialist working in the advisory sphere professionally, who passed an examination, and received a non-certification qualification. An agricultural expert advisor is a registered professional specialist working in the advisory sphere occasionally, who received a qualification certificate under the Law [1]. Usually, expert advisors are employees of scientific or classical institutions and other highly qualified specialists. The training for all kinds of advisers consists of basic and advanced training programs and is performed by institutions at the request of the Central Executive Body governing the agricultural policy, advisory services, an independent organization, etc. Further development of advisors and expert advisers may involve a freelance work. The Central Executive Body for Agrarian Policy may finance the training of advisers and expert advisors within the budget of the specific program for the agricultural advisory activities. 


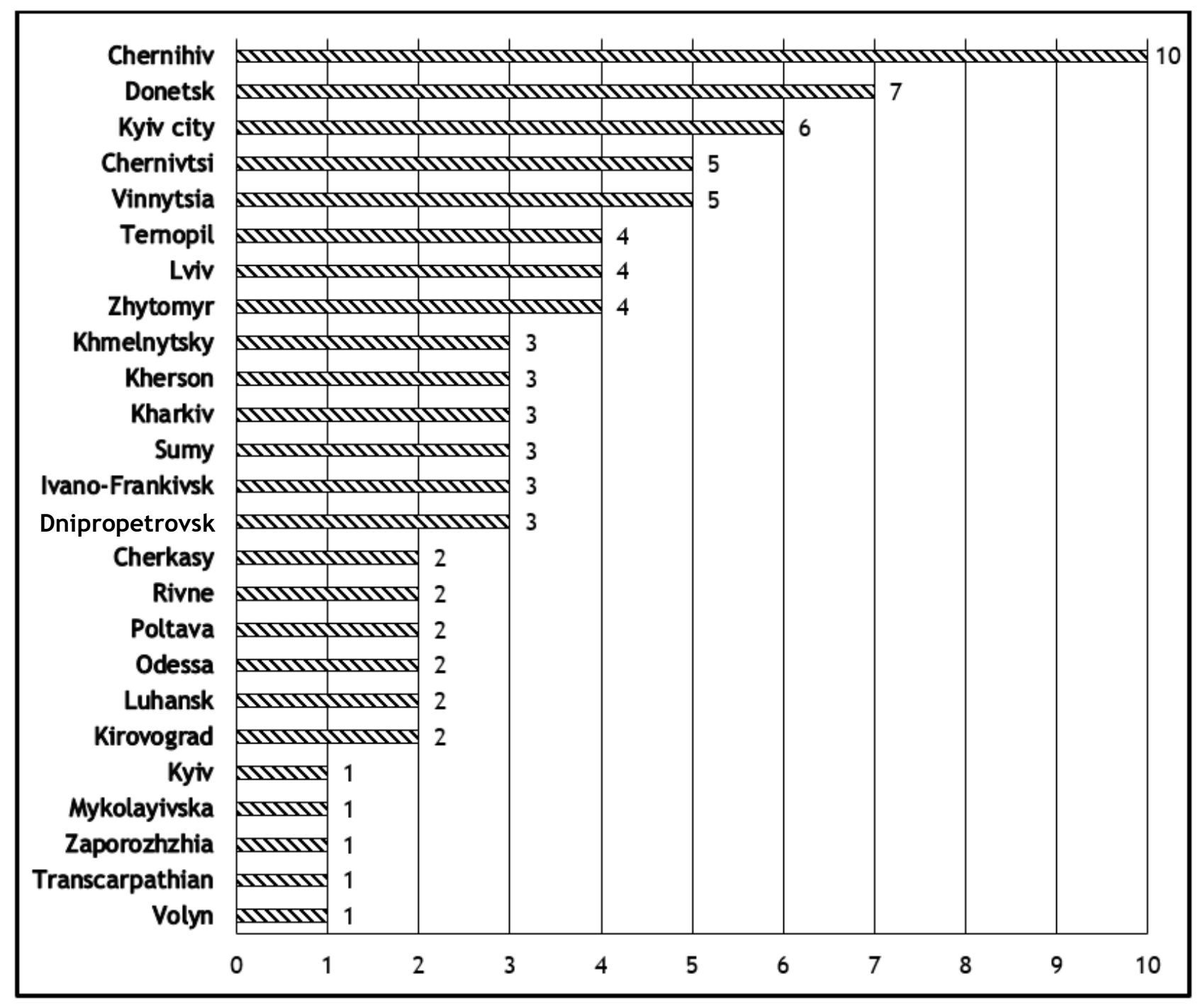

Figure 3. AAS in oblasts of Ukraine, 2020

Source: Created by the authors.

The Register of AAS and Register of agricultural advisers and expert-advisers highlights that 446 persons with a qualifying certificate of adviser and expert-adviser officially work outside the system of advisory services. At the same time, those advisers and expert-advisers can cooperate with the advisory services organization to implement particular tasks or projects based on long-term or short-term contracts.

Evidently, the agricultural advisory system should be unified and operate at such four interacting levels as the state, regional, district, and rural communities. Taking into account the limited public funds and the lack of long-term development policy for the agricultural sector, the creation of a full-fledged system of agricultural advice is problematic. The advisory service system is vital for an agricultural sector based on small and medium-sized businesses in rural areas. People in such areas often do not know what "AAS" is; they do not understand the reasons for using such services and their benefits. Also, they are afraid of being cheated and not used to paying for advisory services [3].

In Ukraine, the policy is different. It affects negatively the development of the advisory service, which faces the following challenges:

- unsatisfied demand for agricultural advisory services in terms of small and medium business development in rural areas, rural development;

- low solvency of the rural population unable to buy advisory and consultancy services;

- underestimation of the role of information in the modern economy both by the authorities and the non-governmental sector;

- the confusing mechanisms for cooperation and involvement with formal institutions;

- low level of governmental support for agriculture advisory activities; 
- lack of a software approach to agriculture advisory activities;

- understaffing of agricultural advisory services $[7,74 \mathrm{p}]$.

Described issues may be resolved by the development strategy for agricultural advisory activities. Besides, such strategy has to include the creation of agricultural market infrastructure, the formation of a marketing network for agricultural products from producer to consumer through rural cooperatives, district cooperative agricultural houses, wholesale markets (fruit and vegetables, food), livestock and poultry auctions, etc [4].

The tasks for the long-term development of advisory activities are:

- to complete the formation of regional advisory services system and its district branches to provide the advisory services to business entities in rural areas and at least $90 \%$ of the rural population of the country;

- to form a market system for the dissemination of agricultural knowledge, technologies and information with the participation of agricultural science, education and agricultural advisory activities to create an effective system of continuing agricultural education, scientific services for agro-industrial production and rural development;

- create conditions for the gradual transition of the advisory system to self-financing.

Conclusions. Like in other countries, the main goals of AAS in Ukraine are spreading the knowledge about modern science and technology and implementing their findings in the production process, providing the agricultural producers and rural population with advice about management, marketing, rural social development. The performance of the agricultural advisory services system is strongly correlated with the research, development, education (formal, non-formal, and informal) and training (including vocational training) systems. Agricultural advisory services can be a powerful tool to help smallholders break the cycle of low productivity, vulnerability, and poverty. By providing farmers with knowledge and tools about modern agricultural practices, linking them to new technology, and providing them greater access to finance and market solutions, AAS can be a critical force for change.
The development of the system of agricultural advisory farmers and bringing it in line with EU requirements will help strengthen the competitiveness of the national producers, and the integrated development of rural areas.

In Ukraine, the average number of AAS per one oblast is 3, and 7 AAS are in Kyiv. The most of AAS organizations is in the Chernihiv oblast, specifically 10, Donetsk oblast has 7 AAS (as of 2014), Vinnytska and Chernivetska oblasts have 5 AAS each. The study shows that $66 \%$ of all advisory service organizations have a non-governmental status, $28 \%$ of those are Limited (LTD) or Private entrepreneur (PE).

So far, only about $14 \%$ of AAS organizations have their website or page on social media. The lack of information negatively affects the promotion of their advisory services and Facebook groups have a very little number of active participants.

The general challenges for AAS organizations in Ukraine were determinated. Mainly, they are low ability of rural population to buy advisory and consultancy services; the confusing mechanisms for cooperation with AAS institution and involvement with formal institutions; low level of governmental support for agriculture advisory activities, and understaffing of agricultural advisory services. In response to such challenges and to create favorable conditions for agricultural advisory development, it is necessary to unite the efforts of advisory services, advisors, producers, and processors of agricultural products, cooperatives, agricultural science and education, international technical assistance projects, the Government, local authorities, rural communities, civil society organizations. As strong agricultural advisory institution promotes the economic cooperation between the Europe and Ukraine within the Association Agreement with the EU. Development of effective and reliable advisory service for agricultural producers and rural population, raising the professional level of advisors and expert advisors need the continued support of the Government. Today, the agricultural advisory is one of the most effective tools that can bring big and small farms to a new level and make them more competitive. 


\section{Список бібліографічних посилань}

1. Безкровний М. Ф. Організація інформаційноконсультаційної діяльності : навч. посіб. Київ : Каравела, 2009. 492 c.

2. Бондарчук Н.В. Інформаційно-консультаційні послуги в сільському господарстві: досвід країн з розвиненою економікою. Ефективна економіка. 2010. № 1. URL: http: / / www.economy. nayka.com.ua/?op $=1 \& z=107$.

3. Галич О. А., Сосновська О. О. Сільськогосподарське дорадництво : навч. посіб. Київ : Центр учбової літератури, 2007. 368 c.

4. Єдина комплексна стратегія розвитку сільського господарства та сільських територій на 2015-2020 роки. Міністерство аграрної політики та продовольства України. URL : https://agro.me.gov.ua/ua.

5. Кальна-Дубінюк Т.П. та ін. Формування та розвиток системи дорадництва в Україні : монографія / Т. П. Ніжин : Видавець ПП Лисенко М. М., 2014. 332 с.

6. Кропивко М. Ф. Інформаційне забезпечення агропромислового виробництва України в ринкових умовах : монографія. Київ : IAЕ УААН, 1996. 160 с.

7. Кулаєць М. М., Безкровний М. Ф. Законодавче врегулювання надання соціально спрямованих дорадчих послуг вищими аграрними навчальними закладами. Агроінком. 2010. № 7-9. C. 74-76.

8. Національна асоціація сільськогосподарських дорадчих служб України. URL : http://www.dorada.org.ua/ about.html.

9. Про сільськогосподарську дорадчу діяльність : Закон України від 17.06.2004 № 1807-IV. Верховна Рада України. URL: http://zakon3.rada.gov.ua/laws/show/1807-15.

10. Стельмащук А. М., Смоленюк П. С. Дорадництво : навч. посіб. Хмельницький: ПП Гонта А.С., 2011. 160 с.

11. Anne W. Van den Ban. Different ways of financing agricultural extension. Agricultural Research \& Extension Network, Network paper. 2010. No. 106, July. P. 1-8.

12. Burton E. Swanson. Global Review of Good Agricultural Extension and Advisory Service. Food and agriculture organization of the United Nations (FAO), Rome 2008. URL : http://www. fao.org/3/i0261e/i0261e00.htm.

13. Naswem A. A., Daudu S., Ejembi E. P. Legislated Policy as the Basis for Effective Extension Delivery. Journal of Agricultural Extension. 2013. Vol. 12(2) December. P. 4-8.

14. Quamar M. K. Modernizing National Agricultural Extension Systems: A Practical Guide for Policy-Makers of Developing Countries. Food and Agricultural Organization of the United Nations (FAO), Rome 2005. 69 p.

\section{References}

1. Bezkrovnyi, M.F. (2009). Orhanizatsiia informatsiinokonsultatsiinoi diialnosti [Organization of information and consulting activities]. Kyiv: Karavela [In Ukrainian].

2. Bondarchuk, N.V. (2010). Informatsiino-konsultatsiini posluhy $v$ silskomu hospodarstvi: dosvid krain $z$ rozvynenoiu ekonomikoiu. [Information and consulting services in agriculture: the experience of countries with developed economies]. Efektyvna ekonomika, 1. Retreived from: http://www.economy.nayka.com.ua/?op=1\&z=107 [In Ukrainian].

3. Halych, O.A., \& Sosnovska, O.O. (2007). Silskohospodarske doradnytstvo: navch. posibnyk [Agricultural advisory: training manual]. Kyiv: Tsentr uchbovoi literatury [In Ukrainian].

4. Yedyna kompleksna stratehiia rozvytku silskoho hospodarstva ta silskykh terytorii na 2015-2020 roky [Integrated Strategy for the Development of Agriculture and Rural Areas for 2015-2020]. Ministerstvo ahrarnoi polityky ta prodovolstva Ukrainy. Retreived from http://minagro.gov.ua/node/16017 [In Ukrainian].

5. Kalna-Dubiniuk, T.P. et al. (2014). Formuvannia ta rozvytok systemy doradnytstva $v$ Ukraini : monohrafiia [Formation and development of an advisory services system in Ukraine: monograph]. Nizhyn: Vydavets PP Lysenko M. M. [In Ukrainian].

6. Kropyvko, M.F. (1996). Informatsiine zabezpechennia ahropromyslovoho vyrobnytstva Ukrainy v rynkovykh umovakh: monohrafiia [Information support of agro-industrial production of Ukraine in market conditions: monograph]. Kyiv: IAE UAAN [In Ukrainian].

7. Kulaiets, M.M., Bezkrovnyi, M.F. (2010). Zakonodavche vrehuliuvannia nadannia sotsialno spriamovanykh doradchykh posluh vyshchymy ahrarnymy navchalnymy zakladamy [Legislative regulation of provision of socially advisory services by higher agricultural educational institution]. Ahroinkom, 7-9, pp. 74-76 [In Ukrainian].

8. Natsionalna asotsiatsiia silskohospodarskykh doradchykh sluzhb Ukrainy [The National Association of Agricultural Advisory Services of Ukraine]. (2016). Retrieved from http://www.dorada.org.ua/about.html [In Ukrainian]

9. Pro silskohospodarsku doradchu diialnist: Zakon Ukrainy vid 17.06.2004 \# 1807-IV [On Agricultural Advisory Activities: Law of Ukraine from 17.06.2004 No. 1807-IV]. Verkhovna Rada Ukrainy. Retrieved from: http://zakon3.rada.gov.ua/laws/show/ 1807-15 [In Ukrainian].

10. Stelmashchuk, A.M., Smoleniuk, P.S. (2011). Doradnytstvo: navch. posib. [Counseling: tutorial]. Khmelnytskyi: PP Honta A.S. [In Ukrainian].

11. Anne, W., Van den Ban. (2010). Different ways of financing agricultural extension. Agricultural Research \& Extension Network, Network paper, 106, pp. 1-8 [In English].

12. Burton, E. Swanson. (2008). Global Review of Good Agricultural Extension and Advisory Service. Food and agriculture organization of the United Nations (FAO), Rome. Retrieved from http://www.fao.org/3/i0261e/i0261e00.htm[In English].

13. Naswem, A.A., Daudu, S. \& Ejembi, E.P. (2013). Legislated Policy as the Basis for Effective Extension Delivery. Journal of Agricultural Extension, vol. 12 (2), pp. 4-8 [In English].

14. . Quamar, M.K. (2005). Modernizing National Agricultural Extension Systems: A Practical Guide for PolicyMakers of Developing Countries. Rome: Food and Agricultural Organization of the United Nations [In English].

\section{Безус Р. М., Дубчак М. О. Генезис та розвиток сільськогосподарських дорадчих служб в Україні}

Мета статmі - розглянути становлення, актуальні проблеми та подальший розвиток сільськогосподарських дорадчих служб в Україні.

Методика дослідження. Використано діалектичні методи пізнання та монографічний метод (для аналізу законодавства, праці українських і зарубіжних учених з проблеми консультаційних послуг у сільському господарстві), емпіричні та графічні методи (для оцінки й демонстрації структури організаційних форм і методів маркетингу консультаційних послуг), абстрактно-логічний метод (для теоретичних узагальнень та формулювання висновків).

Результати дослідження. Встановлено, що інститут сільськогосподарських дорадчих служб є потужним інструментом, який допомагає дрібним власникам в Україні розірвати цикл низької продуктивності, вразливості та бідності. Надаючи фермерам знання та інструменти щодо сучасної сільськогосподарської практики, сільськогосподарські консультаційні послуги можуть стати критичною силою змін. Однак розвиток консультаційних організацій в Україні зараз наражається на такі виклики, як низький рівень державної підтримки сільськогосподарської дорадчої діяльності, недоукомплектованість сільськогосподарських дорадчих служб та заплутані механізми співпраці між офіційними установами й сільськогосподарськими дорадчими службами тощо. 
Елементи наукової новизни. Досліджено сучасні перспективи і проблеми сільськогосподарських дорадчих служб в Україні. Виявлено перспективні точки розвитку і вдосконалення таких організацій для забезпечення підтримки подальшого розвитку сільських територій в Україні. Зокрема, потрібні урядові програми підтримки сільськогосподарської дорадчої діяльності як на рівні дрібних виробників, так і на рівні місцевих органів влади, необхідним $\epsilon$ створення механізмів співпраці між сільськогосподарськими дорадчими службами та офіційними установами в Україні, підтримка професійного розвитку дорадників та експертів.

Практична значущість. Узагальнюючи отримані та проаналізовані дані, можна зробити висновок, що вчені та розробники політики аграрного розвитку можуть використовувати результати дослідження з метою розвитку сільськогосподарських дорадчих служб для підтримки сільського малого бізнесу та поліпшення рівня життя сільських громад. Табл.: 2. Puc.: 3. Бібліогр.: 14

Ключові слова: сільськогосподарські дорадчі служби; сільськогосподарські кооперативи; розвиток села; радники; експерти; малий бізнес.

Безус Роман Миколайович - доктор економічних наук, професор, професор кафедри маркетингу, Дніпровський державний аграрно-економічний університет (49600, м. Дніпро, вул. С. Єфремова, 25)

E-mail: bezusrm@gmail.com

ORCID iD https://orcid.org/0000-0001-5284-9178

Дубчак Марина Олегівна - студентка 2 курсу магістратури факультету менеджменту та маркетингу, Дніпровський державний аграрно-економічний університет (49600, м. Дніпро, вул. С. Єфремова, 25)

E-mail: marina.dubchak.daas@gmail.com

\section{Безус Р. Н., Дубчак М. О. Генезис и развитие сельскохозяйственных консультационных служб в Украчне}

Цель статьи - рассмотреть становление, актуальные проблемы и дальнейшее развитие сельскохозяйственных консультационных служб в Украине.

Методика исследования. Использованы диалектические методы познания и монографический метод (для анализа законодательства, работы украинских и зарубежных учёных по проблеме консультационных услуг в сельском хозяйстве), эмпирические и графические методы (для оценки и демонстрации структуры организационных форм и методов маркетинга консультационных услуг), абстрактно-логический метод (для теоретических обобщений и формулирования выводов).

Результаты исследования. Установлено, что институт сельскохозяйственных консультационных служб является мощным инструментом, который помогает мелким сельхозпроизводителям в Украине разорвать цикл низкой производительности, уязвимости и бедности. Предоставляя фермерам знания и инструменты современной сельскохозяйственной практики, сельскохозяйственные консультационные услуги могут стать критической силой изменений. Однако развитие консультационных организаций в Украине сейчас подвергается следующим вызовам: низкий уровень государственной поддержки сельскохозяйственной консультационной деятельности, недоукомплектованность сельскохозяйственных консультационных служб и запутанные механизмы сотрудничества между официальными учреждениями и сельскохозяйственными консультационными службами и m.n.

Элементы научной новизны. Рассмотрены современные перспективы и проблемы сельскохозяйственных консультационных служб в Украине. Выявлены перспективные точки развития и совершенствования таких организаций для обеспечения поддержки дальнейшего развития сельских территорий в Украине. В частности, нужны программы поддержки сельскохозяйственной консультационной деятельности как на уровне мелких производителей, так и на уровне местных органов власти, необходимо создание механизмов сотрудничества между сельскохозяйственными консультационными службами и официальными учреждениями в Украине, а также поддержка профессионального развития советников и экспертов.

Практическая значимость. Обобщая полученные и проанализированные данные, можно сделать вывод, что ученые и разработчики политики аграрного развития могут использовать результаты исследования в целях развития сельскохозяйственных консультационных служб для поддержки сельского малого бизнеса и улучшения уровня жизни сельских общин. Табл.: 2. Илл.: 3. Библиогр.: 14.

Ключевые слова: сельскохозяйственные консультационные службы; сельскохозяйственные кооперативы; развитие села; советники; эксперты; малый бизнес.

Безус Роман Николаевич - доктор экономических наук, профессор, профессор кафедры маркетинга, Днепровский государственный аграрно-экономический университет (49600, г. Днепр, ул. С. Ефремова, 25)

E-mail: bezusrm@gmail.com

ORCID iD https://orcid.org/0000-0001-5284-9178

Дубчак Марина Олеговна - студентка 2 курса магистратуры факультета менеджмента и маркетинга, Днепровский государственный аграрно-экономический университет (49600, г. Днепр, ул. С. Ефремова, 25)

E-mail: marina.dubchak.daas@gmail.com

The article has been received 05.08.2020

Revision: 12.08 .2020

Бібліографічний опис для цитування:

Bezus R. M., Dubchak M. O. Genesis and development of agricultural advisory services in Ukraine. Економіка АПК. 2020. № 8. С. 52 - 59. https://doi.org/10.32317/2221-1055.202008052

Bezus, R.M. \& Dubchak, M.O. (2020). Genesis and development of agricultural advisory services in Ukraine. Ekonomika APK, 8, pp. 52 - 59 [In English]. https://doi.org/10.32317/2221-1055.202008052 